Kudrenko S.A.

\title{
INFRASTRUCTURE OF PLUG-INS FOR AUTOMATED DESIGN USING CLOUD TECHNOLOGIES
}

\author{
National Aviation University \\ stanislava@i.ua
}

\section{Introduction}

One of the regions that have gotten elevated consideration as of late is the automationof different assignments in the field of designing and engineering. Building Information Modeling (BIM) software solutions today foster 3D intelligent modeling beyond simple geometric forms and shapes. Best practices in BIM implementation have demonstrated the ease of prototyping for designs with non-typical complexities and magnitudes.

All the more frequently it is conceivable to experience this as generative plan. It is picked to call it robotization for this exploration function as it isn't restricted to simply displaying or math, applying computerization for different errands from calculation age to information, boundary the executives, streamlining complex or tedious undertakings, for example, making and arranging plans for Revit, and so on [1].

In work [2] creation of plug-in for automated design of complex engineering objects on Autodesk Revit based was considered. Autodesk Revit object, has its own properties and methods. It is possible with these properties and methods to automate and speed up designing process with the help of programming [3].

Tools created to automate certain processes include numbering reinforcement, elements, inserting custom parameters according to element types or a set of other parameters, generating necessary views of elements. When talking about the extension of Revit capabilities, these usually include placement of elements at specified world coordinates, modelling of complicated geometry and etc.

Design Automation Application Programming Interface (API) for Revit can create cloud-native applications that help in building, extracting, and modifying the Revit data. It enables to automate several tasks like documentation, analyzing the model data, creating customized Revit families [3].

\section{Problem statement}

Paper is devoted to a thorough analysis of information modeling processes, their problems, and options for improvement using the extensive capabilities of programming in tandem with modern Amazon cloud technologies.

Also, it focuses on the direct implementation of a broad infrastructure that includes several Revit plug-ins, a database, a user rights management system, cloud storage, virtual machines for query processing, and many other cloud service components to create a self-contained and useful system.

\section{Usage of Amazon Web Services}

Amazon's cloud platform provides almost every feature in the cloud computing industry. Their cloud services allow easy access to computing power, storage or other features needed by application developers. Amazon web services (AWS) has many products that fall into different categories. In addition to the features mentioned above, they offer developer tools, management tools, mobile services and application services.

Amazon Simple Storage Service (Amazon S3) is an object storage service that offers industry-leading scalability, data availability, security, and performance. This means customers of all sizes and industries can use it to store and protect any amount of data for a range of use cases, such as data lakes, websites, mobile applications, backup and restore, archive, enterprise applications, IoT devices, and big data analytics [4]. 
S3 provides robust access control, cost, replication and data protection capabilities (fig. 1). S3 Access Points make it easy to manage access to data with specific permissions for your applications using a common data set. S3 Replication manages data replication within a region or to other regions. S3 batch operations help manage large-scale changes to billions of objects. Because S3 works with
AWS Lambda, you can log actions, identify alerts and automate workflows without managing additional infrastructure [7].

Run big data analytics on S3 objects (and other data sets in AWS) with Amazon onsite query services. Use Amazon Athena to query S3 data using standard SQL expressions and Amazon Redshift

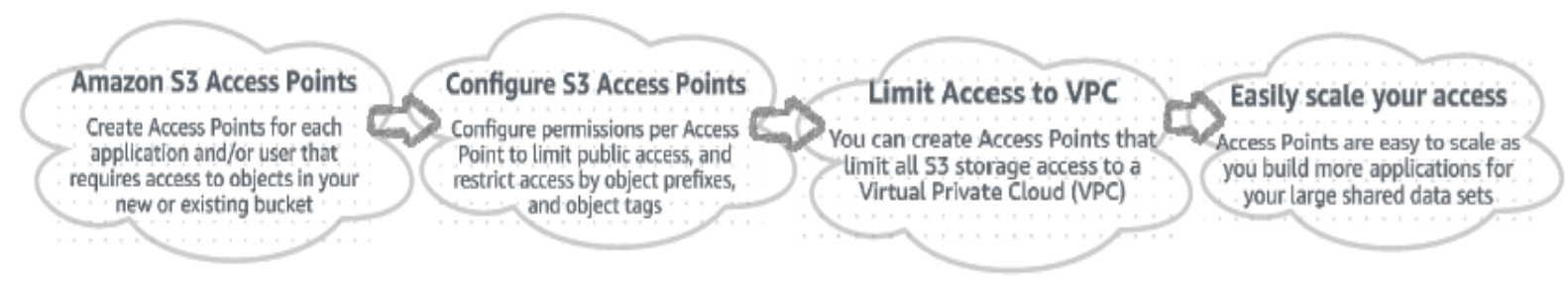

Fig. 1. S3 Access Points functioning

spectrum to analyze the data that's stored in your AWS data stores and S3 resources. It is possible also to use S3 Select to retrieve subsets of object data rather than the entire object.

\section{Plug-in and Its Infrastructure}

Modern projects for the construction of complex engineering objects, different structures and entire city infrastructures take years and thousands of man hours. Numerous engineers of different qualifications (electrical, piping, air conditioning etc.), architectures and specialists make digital models of constructions to calculate its loads, render views and a lot of other vital tasks. This work is filled with routine actions that engages at least half of this time. Engineers arrange electrical equipment, ventilation, piping, heating elements and a lot of the rest manually. But the problem is that to get to, for example, a socket or a lamp, you must press a lot of buttons on different panels, find the desired family of elements through windows explorer and, after loading the whole family into the project, pull out the desired type from there. Family Browser allows you to do it in a few seconds and just in two mouse clicks with clarity and filtering of the desired type. This is a dynamic interface to control, store and locate Revit families and types. Family Browser stays up to date with any changes made in windows explorer. Ideal for any small or large practice no matter what flavor of Autodesk's Revit you use. All families can be controlled from a central location allowing a BIM Manager to instantly make changes, adding groups, tabs or families.

The Features of The Developed Plugin

1. during the installation of the .msi package (which is also ready to use), keys are created in the registry dynamically to control versions and directories, i.e., all libraries, .exe files, local databases and addin files, which Revit needs directly;

2. when we start the audit, the relevance of all files required for the plugin is checked i.e., versions from the server are compared with the versions from the registry of a current user. If there is any update, the user has an opportunity to download all necessary files (families, templates, ifc export, etc.). Downloading these files is not just the case, but using the self-made FamiliesDownloader.exe file, which connects with the server and then downloads only necessary archives, extracts everything from them and distributes its contents into the required directories.

3. to simplify and perceptibly speed up the design in Revit software using the panel. The panel contains types from families that are grouped into categories - family categories are buttons from the header, for example, cables, electrical appliances, safety sensors etc. These types can be double-clicked or dragged into the project without any extra 
effort of uploading family into the project and extract from there a type by yourself.

4. The insertion occurs by a query in the database, which stores all the info about families and its types (path to the family from which to insert it, path to the picture, description, name, installation type, installation place, etc.).

5. the panel on the right displays types from the families of a certain category, which are loaded by clicking on the category from the database.

6. to ease navigating through current types there were created various types of filtering current family types, such as filtering by type / location / installation medium (fig. 2).

Another problem is that one project contains particular standards for families, types, annotations, templates and other. But those standards are often being missed because a lot of engineers can't wait till some special family will be designed for them right here and right now. Therefore, Family Browser application has its own standardchecking pipeline to create, check and push any new family type to standardized database on cloud via AWS instruments. The overview of this method is displayed below: This pipeline can be described as a bunch of simple steps for engineer, but overall, it's a huge infrastructure which consists of Revit plug-ins and Amazon Web Services. This mechanism is performed in the following way:

1. There is a template for each category in Revit on the base of which engineer creates its own family for project. Template is standardized and it is stored in AWS S3 to make it always up to date and easy to download (fig.2).

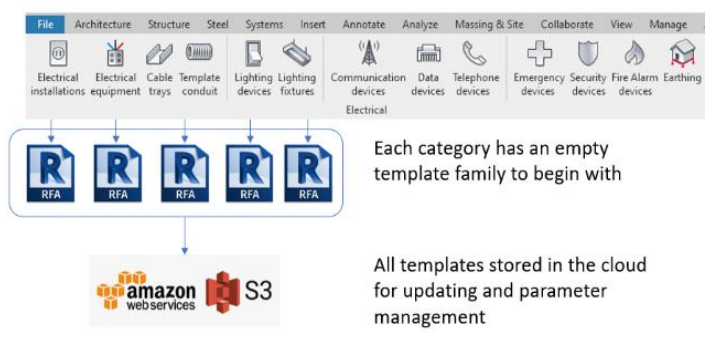

Fig. 2. First step of creating own standardized family
2. After family is created it must be processed by internal FamilyBrowser script, which retrieves all internal parameters of each type and to store in in Amazon RDS. Then starts another Revit addin, called Image Printer. This addin creates images of each type from family automatically. and uploaded to AWS S3. After all new family is being uploaded to AWS S3 as .rfa file (Autodesk Revit file).

3. Next step is all responsible head-engineers and managers receive email or another type of notification that the family is created and its unconfirmed yet (red status). Also, this family is already available in Revit Family Browser application, but with red status.

4. Managers and head-engineers have access to read, modify, delete all families including those unconfirmed. They decide what to do with new family and then set status to yellow (checked) or green (checked and released) or delete family (fig.3)

All families are grouped by category. Once category is selected all available Main Panel can be incorporated to the existing Revit panels such as "Parameters" or "Project Browser". This panel contains filters, list of available types and allows to load them into project.

\section{FamilyBrowser Representational State Transfer Service via Laravel}

Laravel is a PHP framework developed with PHP developer productivity in mind. The framework also aims to evolve with the web and has already incorporated several new features and ideas in the web development world - such as job queues, API authentication out of the box, real-time communication, and much more [9].

First, it is necessary to understand what exactly is considered a Representational State Transfer (REST) API. REST stands for Representational State Transfer and is an architectural style for network communication between applications, which relies on a stateless protocol (usually HTTP) for interaction. 


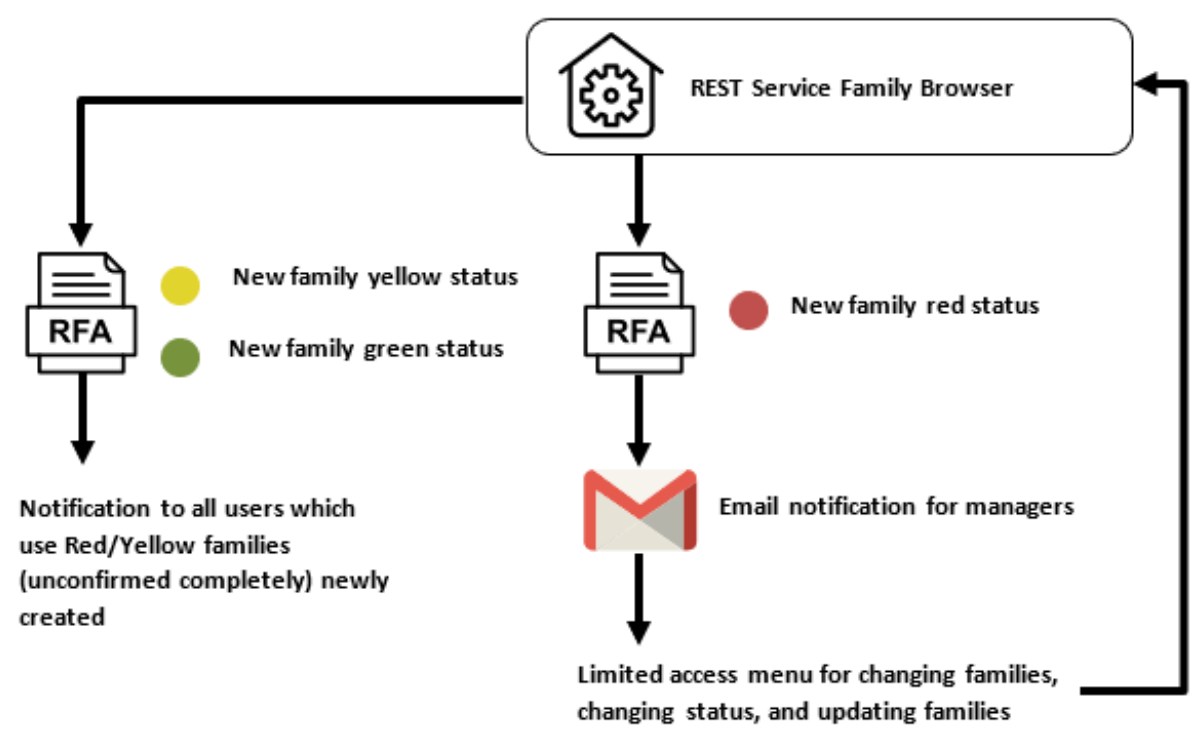

Fig. 3.Family submition process and representation in Revit

In RESTful APIs, we use the HTTP verbs (fig. 4) as actions, and the endpoints are the resources acted upon. There are such HTTP verbs for their semantic meaning:
- GET: retrieve resources

- POST: create resources

- PUT: update resources

- DELETE: delete resources

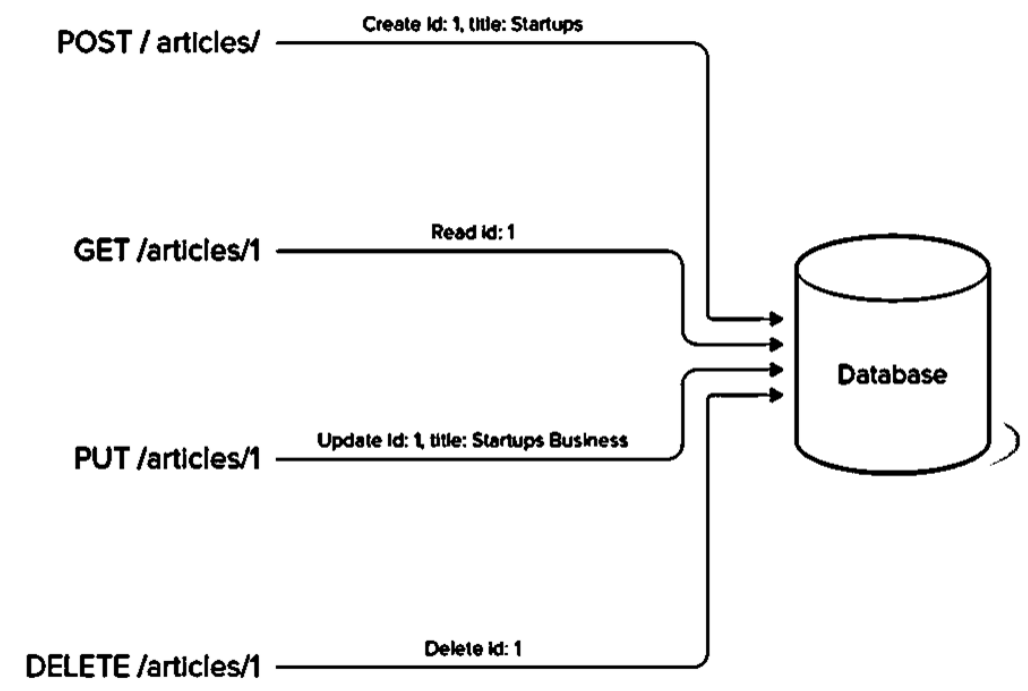

Fig. 4. HTTP requests to database

Resources will be the targets of the actions, in our case Articles and Users, and they have their own endpoints:

- /articles;

- /users.

In this laravel API description, the resources will have a 1:1 representation on our data models, but that is not a requirement. It is allowed to have resources represented in more than one data model (or not represented at all in the database) and models completely off limits for the develpoer. In the end, it is not prohibited to decide how to architect resources and models in a way that is fitting to any kind of application.

\section{Conclusions}

In paper has been created entire infrastructure of Revit plug-ins along with Amazon Web Services to store data, files, send notifications etc. for modeling software of engineering equipment, in this case Autodesk Revit via Revit API for .NET. There was particularly explained working principles and 
functions of Revit Family Browser plug-in and its standards-controlling ecosystem.

The REST service built with the help of Laravel framework was described step by step and its features have been displayed, demonstrating its flexibility, configuration and simpleness.

This part showed how to create installer project and the entire process of creation .msi package for easy distribution of application through Windows computes.

Revit Family Browser application infrastructure with plug-ins and Amazon cloud services stands out with the following advantages:

- increases designing efficiency and speed;

- rich functionality with multiple settings;

- strong standards for projects

- simple new families upload pipeline

- family versions switch

- multilingual support and locations settings for content

- statistics and global search feature to show the most popular items

- REST service for universal and quick data retrieval and uploading

- drag-n-drop types to insert;

- user-friendly design;

- no more loading families via "Load Family" and searching through numerous folders within windows explorer and loading a project with multiple redundant types; agement;

- flexible categories and families man-

- moveable/collapsible browser always stays open and accessible; types;

- filters to ease navigation through

- silent deployment options to firm wide user base;
- - available for Autodesk Revit 2017, 2018, 2019, 2020, 2021.

\section{References}

1. Rowland S. BIM to IoT: the persistence problem. Lecture Notes of the Institute for Computer Sciences. - Porto: 2016. - $138 \mathrm{p}$.

2. Kudrenko S.A. Method for complex objects automated design on autodesk revit based / Kudrenko S.A., Fomina N.B., Kramarenko I.P. / Проблеми інформатизації та управління, 2020. - № 63. - Р. 64-74.

3. BIM Consulting Services / Dynamo vs Revit API. [Electronic resource]. Available at: https://www.elogictech.com/blogs/bloginfo/dynamo-vs-revit-api

4. Amazon Web Services (AWS) Cloud Computing Services. Electronic resource]. / - Available at: https://aws.amazon.com.

5. Rudden K. BIM and ISO 19650 from a project management perspective / Rudden, K. - Booklet on ISO Standard / Efca. Bern. $48 \mathrm{p}$.

6. Guide of Revit Image Printer. [Electronic resource]. / - Available at: https://www.building360.ch/ImagePrinter.

7. Cloud Object Storage | Amazon Simple Storage Service (S3). Electronic resource]. / - Available at: https://aws.amazon.com/s3.

8. Family Browser Help Page Electronic resource]. / - Available at: https://www.building360.ch/FamilyBrowser/ en.

9. Castelo A. Laravel API Tutorial: How to Build and Test a RESTful API. Electronic resource]. / - Available at: https://www.toptal.com/laravel/restfullaravel-api-tutorial.

\section{Kudrenko S.A}

\section{INFRASTRUCTURE OF PLUG-INS FOR AUTOMATED DESIGN USING CLOUD TECHNOLOGIES}

The article is devoted to a thorough analysis of information modeling processes, their problems, and options for improvement using the extensive capabilities of programming. 
Autodesk Revit object, has its own properties and methods. It is possible with these properties and methods to automate and speed up designing process with the help of programming. Also, it focuses on the direct implementation of a broad infrastructure that includes several Revit plug-ins, a database, a user rights management system, cloud storage, virtual machines for query processing, and many other cloud service components to create a self-contained and useful system.

Plug-in for automated design of complex engineering objects which was created and considered in previous work on Autodesk Revit based has evolved in this paper and improvement using the extensive capabilities of programming in tandem with modern Amazon cloud technologies.

Tools created to automate certain processes include numbering reinforcement, elements, inserting custom parameters according to element types or a set of other parameters, generating necessary views of elements. When talking about the extension of Revit capabilities, these usually include placement of elements at specified world coordinates, modelling of complicated geometry and etc.

The Representational State Transfer service built with the help of Laravel framework was described step by step and its features have been displayed, demonstrating its flexibility, configuration and simpleness. work.

Keywords: Computer-aided design, Autodesk Revit, Cloud technologies, Laravel frame-

\section{Кудренко С.O.}

\section{ІНФРАСТРУКТУРА ПЛАГІНУ ДЛЯ АВТОМАТИЗОВАНОГО ПРОЕКТУВАННЯ З ВИКОРИСТАННЯМ ХМАРНИХ ТЕХНОЛОГІЙ}

Стаття присвячена ретельному аналізу процесів та завдань інформаційного моделювання, та варіантів вдосконалення з використанням широких можливостей програмування. Об'єкт Autodesk Revit має свої властивості та методи. За допомогою иих властивостей $і$ методів можна автоматизувати та пришвидшити процес проектування за допомогою програмування. Крім того, основна увага приділяється безпосередній реалізації широкої інфраструктури, щзо включає плагін Revit, базу даних, систему управління правами користувачів, хмарне сховище, віртуальні машини для обробки запитів та багато інших компонентів хмарних служб для створення автономної та корисної системи.

Плагін для автоматизованого проектування складних інженерних об'єктів, який був створений і розглянутий у попередній роботі на базі Autodesk Revit, отримав розвиток у ціий роботі та був вдосконалений з використанням можливостей програмування в тандемі з сучасними хмарними технологіями Атаzоп.

Інструменти, створені для автоматизаџії певних прочесів, включають підсилення нумерації, елементи, вставку нестандартних параметрів відповідно до типів елементів або набору інших параметрів, генерування необхідних видів елементів. Коли мова йде про розширення можливостей Revit, вони зазвичай включають розміщееня елементів за заданими світовими координатами, моделювання складної геометрії тощо.

Передача стану представлення (REST), побудована за допомогою фреймворку Laravel, була описана та показані ї̈ функиії, демонструючи ї̈ гнучкість, конфігурацію ma простоту.

Ключові слова: автоматизоване проектування, Autodesk Revit, хмарні технології, Laravel framework. 